\title{
PEREMPUAN DAN PEMANFAATAN TEKNOLOGI INTERNET DENGAN PENDEKATAN UTAUT
}

\author{
Anita Rahmawaty \\ Jurusan Syariah dan Ekonomi Islam STAIN Kudus \\ Email:itarabma1275@gmail.com
}

\section{ABSTRAK}

Penelitian ini bertujuan untuk menganalisis perilaku pemanfaatan internet pada kaum perempuan dengan menggunakan pendekatan Unified Theory of Acceptance and Use of Technology (UTAUT). Terdapat enam variabel dalam penelitian ini, yaitu ekspektasi kinerja, ekspektasi usaha, pengaruh sosial, kondisi pendukung, efikasi diri dan intensi pemanfaatan internet. Data penelitian ini diperoleh dari 110 responden dengan menggunakan teknik convenience sampling. Teknik pengujian model penelitian ini menggunakan regresi linier berganda. Hasil penelitian ini menunjukkan bahwa ekspektasi kinerja, ekspektasi usaha, kondisi pendukung dan efikasi diri berpengaruh secara positif signifikan terhadap terhadap intensi pemanfaatan internet. Namun demikian, pengaruh sosial tidak berpengaruh secara signifikan terhadap intensi pemanfaatan internet.

Kata Kunci: Perempuan, internet, efikasi diri, Unified Theory of Acceptance and Use of Technology. 


\section{ABSTRACT}

This research aims to analyze the behavior of internet use on women by using Unified Theory of Acceptance and Use of Technology (UTAUT). There are six variables in this research, namely the performance expectancy, effort expectancy, social influence, facilitating conditions, self-efficacy and intention of internet use. The data were obtained from 110 respondents by using convenience sampling technique. The research model testing technique used the multiple linear regression approach. The results showed that performance expectancy, effort expectancy, facilitating conditions, and self-efficacy positively and significantly had effects on intention of internet use. Nevertheles, the social influence is not related to intention of internet use.

Keywords: Women, internet, self-efficacy, Unified Theory of Acceptance and Use of Technology.

\section{A. Pendahuluan}

Kemajuan di bidang Teknologi Informasi dan Komunikasi (TIK) mendukung perkembangan teknologi internet. TIK dapat memenuhi kebutuhan informasi dunia dengan sangat cepat, tepat waktu, relevan dan akurat (Nasution, 2004: 1). Hal tersebut mengubah abad informasi menjadi abad internet. Namun demikian, penggunaan internet oleh kaum perempuan relatif tertinggal dibandingkan lakilaki. Hal ini ditunjukkan dengan jumlah pengguna internet kaum perempuan lebih kecil dibandingkan dengan laki-laki yaitu hanya sebesar $26,4 \%$ dari seluruh pengguna internet padahal survei yang dilakukan The International Telecommunication Union (ITU) di enam wilayah yang berbeda pada tahun 2002 mengindikasikan bahwa 99\% perempuan merasa TIK sangat penting dalam mencapai upaya pemberdayaan pribadi, kewirausahaan dan tujuan profesional (Farida, Ratih dan Yudha, 2010: 91).

Kementerian Pemberdayaan Perempuan juga mengemukakan bahwa bidang teknologi, khususnya TIK masih dekat dengan 
identitas laki-laki, sedangkan perempuan seringkali hanya sebagai obyek padahal kuantitas jumlah perempuan hampir separoh dari penduduk Indonesia yang memiliki potensi jika diberdayakan dengan baik. Untuk itu, dipandang perlu untuk memberdayakan perempuan menjadi melek teknologi dan informasi (Farida, Ratih dan Yudha, 2010: 91).

Hermana, Farida dan Adrianti (2007: 1-2) menunjukkan hasil studi yang dilakukan oleh Academy for Educational Development bahwa dari data sekitar 30 negara, penggunaan internet di negaranegara berkembang kurang dari $1 \%$ dari total penduduk, sedangkan perempuan pengguna internet hanya 22\% di Asia, 38\% di Amerika Latin, 6\% di Timur Tengah dan hanya sedikit di Afrika. Pengguna internet dari kalangan perempuan tersebut lebih banyak berasal dari daerah perkotaan, berpendidikan tinggi dan sebagian besar menggunakan komputer dalam pekerjaan rutin di perkantoran.

Sebagai produk sosial, berbagai teknologi, termasuk internet bersifat tidak bebas nilai atau budaya. Tingkat kompabilitas antara nilai dan norma teknologi dengan nilai dan norma yang dianut penggunanya mempengaruhi pola penggunaan teknologi tersebut. Hasil studi Gefen dan Straub dalam Hermana, Farida dan Adrianti (2007: 3) menunjukkan bahwa gender mempengaruhi keberadaan sosial dari internet, persepsi kemudahan penggunaan internet dan persepsi manfaat internet. Persepsi perempuan mengenai keberadaan sosial dari internet adalah lebih tinggi dibandingkan dengan laki-laki. Persepsi manfaat internet juga lebih tinggi dilihat oleh perempuan dibandingkan laki-laki, tetapi laki-laki cenderung lebih mudah menggunakan internet dibandingkan dengan perempuan.

Sementara itu, Ramilo dalam Hermana, Farida dan Adrianti (2007: 3) menyebutkan bahwa dampak TIK terhadap perkembangan ekonomi, politik dan sosial sudah menjadi perhatian utama di beberapa negara di Asia. Dalam sepuluh tahun terakhir, banyak negara yang mengembangkan strategi dan kebijakan yang sebagian besar menitikberatkan pada pelaksanaan strategi dan kebijakan 
pada bidang ekonomi dengan memberikan promosi daya tarik untuk industri TIK, termasuk deregulasi industri telekomunikasi, menarik investor asing dan meningkatkan konektivitas internet. Namun demikian, meskipun terjadi kemajuan pada industri TIK, keuntungan TIK tidak bisa dinikmati oleh sebagian besar masyarakat, terutama di negara-negara berkembang. Difusi teknologi komunikasi dan internet sebagian besar terkonsentrasi di perkotaan, masyarakat berpendapatan tinggi dan orang-orang berpendidikan saja. Perempuan sendiri, secara umum, terpinggirkan, yang sebagian besar tidak memiliki daya beli dan tidak memiliki akses ke alat komunikasi modern.

Para orang tua perlu mengetahui berbagai manfaat dari internet, tetapi juga harus mempertimbangkan dampak negatif dan potensi bahaya dari dunia internet tersebut. Hermana, Farida dan Adrianti (2007: 3) melaporkan hasil penelitiannya bahwa para orang tua merasa cemas dan tidak aman mengenai penggunaan internet oleh anak-anaknya. Untuk itu, para orang tua harus memberikan perhatian terhadap aspek keselamatan dalam penggunaan internet oleh anak-anak dan remaja. Internet memberikan akses pengetahuan yang luar biasa, namun memiliki tiga bahaya utama, yaitu bahaya individu, pengungkapan materi yang tidak layak dan serangan terhadap kerahasiaan pribadi.

Untuk itu, penggunaan teknologi internet bagi kaum perempuan memiliki beberapa tujuan, di antaranya adalah untuk memenuhi kebutuhan pribadi, seperti kebutuhan memperoleh informasi yang berkaitan dengan masalah pekerjaan, dunia kewanitaan atau rumah tangga dan atau bisnis di dunia maya dan kecemasan terhadap dampak negatif dari penggunaan internet oleh anak-anak.

Pada awalnya, teknologi informasi (TI) masih jarang diadopsi oleh kaum perempuan. Hal ini disebabkan oleh berbagai kendala yang dihadapi kaum perempuan dalam mengakses TI, di antaranya: tingkat ketrampilan dan pendidikan yang rendah, masalah bahasa, keterbatasan waktu, masalah biaya akses internet, keterbatasan 
lokasi fasilitas koneksi, norma budaya dan sosial serta ketrampilan manajemen dan komputer yang tidak memadai. Namun kondisi seperti ini lambat laun mulai berubah, seiring dengan mulai timbulnya ketergantungan yang besar dari proses pendidikan dan kebutuhan informasi yang lebih mudah dan cepat diperoleh dari TI. Saat ini, banyak para perempuan yang sudah mulai menyadari pentingnya peran TI dalam meningkatkan efisiensi dan efektivitas kinerja, baik dalam pekerjaan atau bisnis (Nurhadi, 2010: 1).

Pesatnya perkembangan dan penggunaan TI telah mengundang banyak peneliti untuk melakukan penelitian di bidang ini. Beberapa model telah dibangun untuk menganalisis faktor-faktor yang mempengaruhi diterimanya penggunaan TI, diantaranya adalah Innovation Diffusion Theory (IDT), Theory of Reasoned Action (TRA), Theory of Planned Behavior (TPB), Technology Acceptance Model (TAM) dan UTAUT (Unified Theory of Acceptance and Use of Technology) sebagai model paling mutakhir (Hernandoz dan Mazzon, 2007: 75).

Salah satu model mutakhir untuk menjelaskan penerimaan pengguna dalam bidang TIK telah dikembangkan oleh Venkatesh, dkk (2003: 425-426) yang diberi nama model "UTAUT (Unified Theory of Acceptance and Use of Technology)." Model UTAUT menunjukkan bahwa niat untuk berperilaku dan perilaku untuk menggunakan suatu teknologi dipengaruhi oleh persepsi orang-orang terhadap ekspektansi kinerja (performance expectancy), ekspektansi usaha (effort expectancy), pengaruh sosial (social influence) dan kondisi pendukung (facilitating conditions) yang dimoderatori oleh jenis kelamin (gender), usia (age), pengalaman (experience) dan kesukarelaan (voluntaries). Teori ini menyediakan alat bagi para manajer untuk menilai kemungkinan keberhasilan pengenalan teknologi baru dan membantu mereka memahami faktor penggerak penerimaan dengan tujuan untuk proaktif mendesain intervensi (termasuk pelatihan, sosialisasi dan lain-lain) yang ditargetkan pada populasi pengguna yang mungkin cenderung kurang untuk 
mengadopsi dan menggunakan sistem baru.

Model asli UTAUT divalidasi menggunakan data yang dikumpulkan dari lingkungan non akademik. Meskipun demikian, beberapa penelitian terdahulu telah menerapkan model di lingkungan akademik. Sedana dan Wijaya (2010: 31) menerapkan model UTAUT untuk memahami persepsi mahasiswa Universitas Sanata Dharma terhadap penerimaan dan penggunaan Exelsa. Hasil penelitiannya menunjukkan bahwa variabel performance expectancy, social influence dan facilitating conditions terbukti signifikan mempengaruhi behavioral intention, sedangkan effort expectancy terbukti tidak signifikan. Prasetyo dan Anubhakti (2011: 46) dalam studinya melaporkan tentang sikap dan perilaku mahasiswa Universitas Budi Luhur dalam penerimaan dan penggunaan sistem e-learning bahwa performance expectancy, effort expectancy dan social influence terbukti signifikan mempengaruhi sikap untuk menggunakan e-learning system, sedangkan facilitating conditions terbukti tidak signifikan.

Studi Oswari Teddy, dkk (2008: 1) memvalidasi data yang dikumpulkan dari lingkungan bisnis UKM menunjukkan bahwa ada pengaruh yang signifikan dari variabel prediktor (performance expectancy, effort expectancy, social influence dan facilitating conditions) terhadap tingkat penggunaan TI, khususnya pada pembuatan laporan keuangan. Selain itu, terdapat pengaruh yang signifikan juga dari variabel moderating, yang terdiri dari jenis kelamin, usia, pengalaman dan kewajiban menggunakan suatu sistem informasi yang mempengaruhi variabel prediktor terhadap tingkat penggunaan dan kinerja perusahaan.

Sementara itu, studi pendahuluan Hermana, Farida dan Adrianti (2007: 1) menunjukkan bahwa kelompok internet adopter kaum ibu menunjukkan ekspektasi kinerja, ekspektasi usaha, internet self-efficacy dan pengaruh sosial lebih tinggi dibandingkan dengan kelompok potential adopter dan non adopter, sedangkan kelompok non adopter menunjukkan internet anxiety relatif lebih tinggi 
dibandingkan dengan kelompok adopter dan potential adopter. Namun, studi ini hanya sebatas pada pengujian instrumen penelitian dan belum menghasilkan sebuah hasil penelitian. Sedangkan Farida, Ratih dan Yudha (2010: 91) juga melaporkan studinya mengenai model prediksi adopsi internet pada ibu guru SD di Jakarta Selatan dengan menggunakan 5 (lima) prediktor dari model UTAUT, yaitu performance expectancy, effort expectancy, internet anxiety, internet self-efficacy dan social influence. Hasil penelitiannya menunjukkan bahwa kelompok internet adopter cenderung menunjukkan performance expectancy, effort expectancy, internet self-efficacy dan social influence yang lebih tinggi, sedangkan kelompok potential adopter dan non adopter menunjukkan tingkat kecemasan yang tinggi terhadap internet.

Berbeda dengan penelitian terdahulu diatas, studi ini bertujuan untuk mengetahui dan menganalisis perilaku pemanfaatan internet pada kaum perempuan dan menguji pengaruh efikasi diri dengan menggunakan model UTAUT sebagai model dasar perilaku, yang diprediksi mampu mempengaruhi intensi pemanfaatan internet pada kaum perempuan. Studi ini diharapkan dapat memberikan kontribusi dalam membangun perilaku pemanfaatan teknologi internet pada kaum perempuan di Kabupaten Kudus dengan menggunakan variabel-variabel prediktor dari model UTAUT sehingga dapat dijadikan rujukan sebagai model perilaku pemanfaatan internet pada kaum perempuan; memberikan informasi kepada pemerintah dalam mengembangkan teknologi internet bagi kaum perempuan di Kabupaten Kudus dan memacu proses peningkatan dan pengembangan SDM perempuan secara cepat, mudah dan efisien berbasis sistem teknologi informasi sehingga dapat meningkatkan kualitas SDM perempuan yang handal, unggul dan berdaya saing.

\section{B. Pembahasan}

\section{Sistem Informasi dan Teknologi Internet}


Istilah sistem informasi dan teknologi informasi (TI) sering rancu penggunaannya. Bahkan pada akhirnya, istilah TI kini menjadi lebih populer dan menggantikan posisi sistem informasi. Kenyataannya, sistem informasi mencakup aspek yang lebih luas dari TI. Sistem informasi didefinisikan oleh Husein dan Wibowo (2002: 8-11) sebagai seperangkat komponen yang saling berhubungan yang berfungsi mengumpulkan, memproses, menyimpan, dan mendistribusikan informasi untuk mendukung pembuatan keputusan dan pengawasan dalam organisasi. Dari sudut pandang bisnis, sistem informasi bukanlah sekedar input, processing dan output semata. Sistem informasi dalam perspektif bisnis adalah pemecahan masalah manajemen dan organisasi berlandaskan pada teknologi informasi untuk menghadapi tantangan dari lingkungannya. Dengan kata lain, salah satu sub sistem dari sistem informasi adalah teknologi informasi.

William Sawyer dalam Suyanto (2005: 10) mendefinisikan TI sebagai suatu teknologi yang menghasilkan, memanipulasi, menyimpan, mengkomunikasikan dan atau menyampaikan informasi. Sementara itu, Martin et.al. dalam Suyanto (2005: 10) mengartikan TI adalah kombinasi teknologi komputer, baik perangkat keras dan perangkat lunak untuk mengolah dan menyimpan informasi dengan teknologi komunikasi untuk melakukan transmisi informasi.

Dari beberapa definisi di atas dapat disimpulkan bahwa TI selain sebagai teknologi komputer (hardware dan software) untuk pemrosesan dan penyimpanan informasi, juga berfungsi sebagai teknologi komunikasi untuk penyebaran informasi. Sebagai teknologi komputer, teknologi informasi digunakan untuk menerima input, menjalankan proses, menyimpan dan mengakses data, menghasilkan dan menginginkan output serta membantu pengendalian sistem secara keseluruhan. Sebagai teknologi komunikasi, TI digunakan untuk menghasilkan output yang berguna bagi pemakai, dapat dikomunikasikan dengan pemakai lain ke dalam maupun ke luar organisasi melalui jaringan Local Area Network (LAN), Wide Area 
Network (WAN) maupun internet (Halim, 2004: 121).

Komponen-komponen utama yang terdapat dalam infrastruktur TI, di antaranya adalah perangkat keras (hardware), perangkat lunak (software), fasilitas jaringan dan komunikasi, database dan pengguna (brainware) (Suyanto, 2005: 11). Elemen-elemen tersebut saling berinteraksi dan dihubungkan dengan suatu perangkat masukan keluaran (input-output media) yang sesuai dengan fungsinya masingmasing. Perangkat keras (hardware) adalah media yang digunakan untuk memproses informasi, sedangkan perangkat lunak (software) yaitu sistem dan aplikasi yang digunakan untuk memproses masukan (input) menjadi informasi yang berkualitas.

Menurut O'Brien dalam Najoan (2006: 12-13), informasi yang berkualitas adalah informasi yang memenuhi 3 (tiga) dimensi, yaitu: (a) dimensi waktu, meliputi: timeliness (informasi harus tersedia pada saat dibutuhkan; currency (informasi yang tersedia harus up to date); frequency (informasi yang tersedia merupakan informasi yang dibutuhkan); dan time period (informasi yang tersedia meliputi periode lalu, periode saat ini dan periode masa depan; (b) dimensi isi, meliputi: accuracy (informasi yang tersedia harus terbebas dari kesalahan); relevancy (informasi yang tersedia harus berkaitan dengan kebutuhan pengguna informasi); completeness (semua informasi yang dibutuhkan harus tersedia); conciseness (informasi yang dibutuhkan saja yang harus tersedia); scope (informasi dapat memiliki jangkauan yang luas maupun terbatas); performance (informasi dapat menunjukkan kinerja dengan mengukur aktivitas yang dikerjakan) dan (c) dimensi bentuk, meliputi: clarity (informasi yang tersedia mudah dipahami); detail (informasi yang tersedia dalam bentuk perincian maupun ringkasan); order (informasi dapat disusun dalam urutan yang telah ditetapkan sebelumnya); presentation (informasi dapat tersedia dalam bentuk naratif, angka, grafik, dan sebagainya); dan media (informasi dapat disajikan dalam bentuk kertas, tampilan monitor, dan sebagainya).

Sementara itu, pengguna (brainware) merupakan komponen 
yang terpenting karena fungsinya sebagai pengembang hardware dan software serta sebagai pelaksana (operator) masukan (input) dan sekaligus penerima keluaran (output) sebagai pengguna sistem (user) (Nasution, 2004: 1). Pengguna sistem adalah manusia (man) yang secara psikologi memiliki suatu perilaku (behavior) tertentu yang melekat pada dirinya sehingga aspek perilaku dalam penerapan TI merupakan salah satu aspek yang penting untuk diperhatikan. Hal ini dikarenakan interaksi antara pengguna dengan TI sangat dipengaruhi oleh persepsi, sikap dan afeksi pengguna terhadap TI tersebut. Dengan demikian, penerapan suatu TI tidak terlepas dari aspek perilaku karena pengembangan sistem informasi terkait dengan masalah individu dan organisasi sebagai pengguna sistem tersebut sehingga sistem informasi yang dikembangkan harus berorientasi kepada pengguna.

\section{Internet: Sejarah dan Manfaatnya}

Cikal bakal jaringan Internet pertama kali dikembangkan tahun 1969 oleh Departemen Pertahanan Amerika Serikat dengan nama ARPAnet (US Defense Advanced Research Projects Agency). Di awal 1980-an, ARPANET terpecah menjadi dua jaringan, yaitu ARPANET dan Milnet (sebuah jaringan militer), tetapi keduanya mempunyai hubungan sehingga komunikasi antar jaringan tetap dapat dilakukan. Pada mulanya jaringan interkoneksi ini disebut DARPA Internet, selanjutnya disebut Internet saja. Sesudahnya, internet mulai digunakan untuk kepentingan akademis dengan menghubungkan beberapa perguruan tinggi, masing-masing UCLA, University of California at Santa Barbara, University of Utah, dan Stanford Research Institute (Ramadhani, 2003: 2).

Setelah itu, disusul dengan dibukanya layanan Usenet dan Bitnet yang memungkinkan internet diakses melalui sarana komputer pribadi (PC). Sementara itu, protokol standar TCP/IP mulai diperkenalkan pada tahun 1982, disusul dengan penggunaan sistem DNS (Domain Name Service) pada 1984. Selanjutnya, pada 
tahun 1986 lahir National Science Foundation Network (NSFNET), yang menghubungkan para periset di seluruh negeri dengan 5 buah pusat super komputer. Jaringan ini kemudian berkembang untuk menghubungkan berbagai jaringan akademis lainnya yang terdiri atas universitas dan konsorsium-konsorsium riset. NSFNET kemudian mulai menggantikan ARPANET sebagai jaringan riset utama di Amerika hingga pada bulan Maret 1990 ARPANET secara resmi dibubarkan. Pada saat NSFNET dibangun, berbagai jaringan internasional didirikan dan dihubungkan ke NSFNET. Australia, negara-negara Skandinavia, Inggris, Perancis, jerman, Kanada dan Jepang segera bergabung ke dalam jaringan ini (Ramadhani, 2003: $3)$.

Penggunaan internet secara komersial dimulai pada 1994 dipelopori oleh perusahaan Pizza Hut, dan Internet Banking pertama kali diaplikasikan oleh First Virtual. Setahun kemudian, Compuserve, America Online, dan Prodigy mulai memberikan layanan akses ke Internet bagi masyarakat umum. Sementara itu, Indonesia baru bisa menikmati layanan Internet komersial pada sekitar tahun 1994. Sebelumnya, beberapa perguruan tinggi seperti Universitas Indonesia telah terlebih dahulu tersambung dengan jaringan internet melalui gateway yang menghubungkan universitas dengan network di luar negeri (Ramadhani, 2003: 4).

Internet sebenarnya mengacu kepada istilah untuk menyebut sebuah jaringan, bukannya suatu aplikasi tertentu. Karenanya, internet tidaklah memiliki manfaat apa-apa tanpa adanya aplikasi yang sesuai. Internet menyediakan beragam aplikasi yang dapat digunakan untuk berbagai keperluan. Beberapa aplikasi yang paling sering dimanfaatkan oleh pengguna internet, sebagaimana dikemukakan oleh Ramadhani (2003: 6-11), antara lain adalah:

a. WWW (World Wide Web)

Dewasa ini, www atau yang sering disebut sebagai "web" adalah merupakan aplikasi internet yang paling populer. Secara teknis, web adalah sebuah sistem di mana informasi dalam bentuk 
teks, gambar, suara, dan lain-lain yang tersimpan dalam sebuah internet webserver dipresentasikan dalam bentuk bypertext. Informasi di web dalam bentuk teks umumnya ditulis dalam format HTML (Hypertext Markup Language). Informasi lainnya disajikan dalam bentuk grafis (dalam format GIF, JPG, PNG), suara (dalam format AU, WAV), dan objek multimedia lainnya (seperti MIDI, Shockwave, Quicktime Movie, 3D World). Seiring dengan semakin berkembangnya jaringan internet di seluruh dunia, maka jumlah situs web yang tersedia juga semakin meningkat. Hingga saat ini, jumlah halaman web yang bisa diakses melalui internet telah mencapai angka miliaran. Untuk memudahkan penelusuran halaman web, terutama untuk menemukan halaman yang memuat topik-topik yang spesifik, maka para pengakses web dapat menggunakan suatu search engine (mesin pencari). Penelusuran berdasarkan search engine dilakukan berdasarkan kata kunci (keyword) yang kemudian akan dicocokkan oleh search engine dengan database (basis data) miliknya. Dewasa ini, search engine yang sering digunakan antara lain adalah google (www.google.com) dan yahoo (www.yahoo.com).

b. Electronic Mail/Email/Messaging

Email atau surat elektronik adalah aplikasi yang memungkinkan para pengguna internet untuk saling berkirim pesan melalui alamat elektronik di internet. Para pengguna email memilki sebuah mailbox (kotak surat) elektronik yang tersimpan dalam suatu mailserver. Suatu Mailbox memiliki sebuah alamat sebagai pengenal agar dapat berhubungan dengan mailbox lainnya, baik dalam bentuk penerimaan maupun pengiriman pesan.

c. File Transfer

Fasilitas ini memungkinkan para pengguna internet untuk melakukan pengiriman (upload) atau menyalin (download) sebuah file antara komputer lokal dengan komputer lain yang terhubung dalam jaringan internet. Protokol standar yang digunakan untuk keperluan ini disebut sebagai File Transfer Protocol (FTP). 
d. IRC (Internet Relay Chat)

Layanan IRC, atau biasa disebut sebagai "chat” adalah sebuah bentuk komunikasi di intenet yang menggunakan sarana baris-baris tulisan yang diketikkan melalui keyboard. Dalam sebuah sesi chat, komunikasi terjalin melalui saling bertukar pesan-pesan singkat. kegiatan ini disebut chatting dan pelakunya disebut sebagai chatter. Para chatter dapat saling berkomunikasi secara berkelompok dalam suatu chat room dengan membicarakan topik tertentu atau berpindah ke modus private untuk mengobrol berdua saja dengan chatter lain. Belakangan, dengan semakin tingginya kecepatan akses internet, maka aplikasi chat terus diperluas sehingga komunikasi tidak hanya terjalin melalui tulisan namun juga melalui suara (teleconference), bahkan melalui gambar dan suara sekaligus (video conference).

Dewasa ini, penggunaan internet telah merasuk pada hampir semua aspek kehidupan, baik sosial, ekonomi, pendidikan, hiburan, bahkan keagamaan. Internet banyak memberikan keuntungan bagi penggunanya. Beberapa manfaat yang diperoleh melalui internet, menurut Nurastuti (2011: 114), antara lain adalah: pertama, kemudahan dalam mencari informasi. Internet memungkinkan siapapun mengakses berita-berita terkini melalui koran elektronis, seperti Republika online (www.republika.co.id) dan kompas Cyber Media (www.kompas.com) atau sumber lain, seperti CNN News (www.cnn.com). Hasil riset dalam bentuk abstrak, makalah lengkap, majalah, katalog atau bahkan buku juga dapat diperoleh secara online. Kedua, internet mendukung transaksi dan operasi bisnis, yang sering disebut dengan e-Business. Ketiga, berbagai aktivitas baru dapat ditangani oleh internet, seperti sistem pembelajaran jarak jauh (distance learning atau e-learning), sistem telepon dengan biaya rendah, pencarian lowongan kerja, transfer uang, dan lain-lain.

Namun demikian, internet juga memiliki dampak negatif, di antaranya adalah kemudahan orang lain untuk menjiplak karya orang lain (plagiasi), kejahatan penggunaan kartu kredit, perusakan sistem dengan virus, penayangan pornografi, dan lain-lain. 
3. Unified Theory of Acceptance and Use of Technology (UTAUT)

Unified Theory of Acceptance and Use of Technology (UTAUT) merupakan salah satu model penerimaan teknologi yang dikembangkan oleh Venkatesh, dkk (2003: 425). UTAUT model mensintesis elemen pada 8 (delapan) model penerimaan teknologi informasi terkemuka untuk memperoleh kesatuan pandangan mengenai penerimaan pengguna. Kedelapan teori tersebut disatukan di dalam UTAUT adalah theory of reasoned action (TRA), technology acceptance model (TAM), motivational model (MM), theory of planned behavior (TPB), combined TAM dan TPB, model of PC utilization (MPTU), innovation diffusion theory (IDT) dan social cognitive theory (SCT).

Model UTAUT memiliki 4 (empat) konstruk yang memainkan peran penting sebagai determinan langsung dari behavioral intention dan use behavior, yaitu performance expectancy, effort expectancy, social influence dan facilitating conditions. Di samping itu, terdapat 4 (empat) moderator, yaitu gender, age, experiences dan voluntariness yang diposisikan untuk memoderasi dampak dari konstruk-konstruk pada behavioral intention dan use behavior (Venkatesh, 2003: 446447) Secara jelas, model UTAUT dapat digambarkan sebagai berikut:

Gambar 1. Model UTAUT

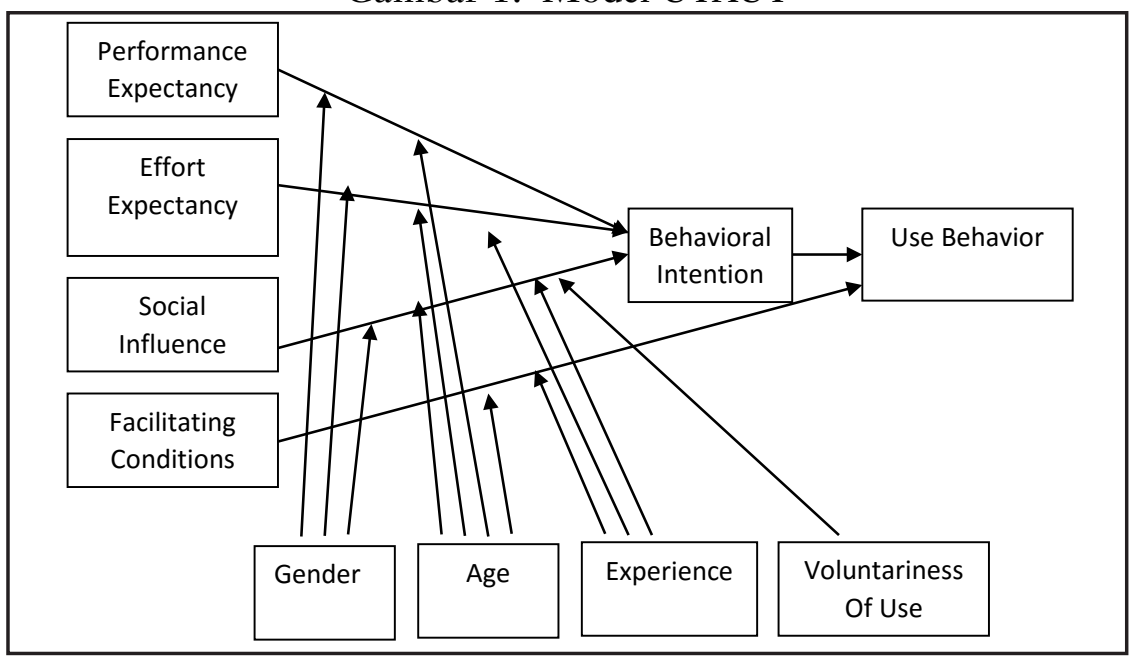

Sumber: Venkatesh, dkk (2003: 447) 
Performance expectancy didefinisikan sebagai "the degree to which an individual believes that using the system will help him or her to attain gains in job performance." Definisi ini menggambarkan bahwa ekspektasi kinerja adalah tingkat kepercayaan seorang individu bahwa penggunaan sistem akan membantunya untuk mencapai kinerja pekerjaannya. Variabel performance expectancy dalam model UTAUT ini disusun berdasarkan 5 (lima) konstruk pada model atau teori sebelumnya, yaitu perceived usefulness (TAM/TAM2 and C-TAM-TPB), extrinsic motivation (MM), job-fit (MPCU), relative advantage (IDT) dan outcome expectations (SCT) (Venkatesh, 2003: 447).

Sedangkan effort expectancy didefinisikan sebagai "the degree of ease associated with the use of the system". Defnisi ini menggambarkan bahwa ekspektasi usaha merupakan tingkat kemudahan yang berhubungan dengan penggunaan sistem. Variabel effort expectancy diformulasikan berdasarkan 3 konstruk pada model sebelumnya, yaitu perceived ease of use (TAM/TAM2), complexity (MPCU) dan ease of use (IDT) (Venkatesh, 2003: 450).

Social influence didefinisikan sebagai "the degree to which an individual perceives that important others believe he or she should use the new system". Definisi ini menggambarkan bahwa pengaruh sosial adalah tingkat persepsi seseorang bahwa pihak lain percaya bahwa sebaiknya dia menggunakan sistem baru. Pengaruh sosial merupakan faktor penentu secara langsung terhadap niat menggunakan teknologi informasi yang direpresentasikan sebagai subjective norm dalam TRA, TAM2, TPB/DTPB dan C-TAM-TPB, social factors dalam MPCU, dan image dalam IDT. Sementara itu, Thompson, dkk sebagaimana dikemukakan oleh Venkatesh, dkk (2003: 451) menggunakan istilah lain, yaitu "social norms" yang memiliki kemiripan dengan subjective norm dalam TRA.

Sementara itu, facilitating conditions didefinisikan sebagai "the degree to which an individual believes that an organizational and technical infrastructure exists to support use of the system". 
Definisi ini menggambarkan bahwa kondisi pendukung adalah tingkat kepercayaan seorang individu bahwa infrastruktur organisasi dan teknik tersedia untuk mendukung penggunaan sistem. Variabel facilitating conditions ini didasarkan pada 3 (tiga) konstruk pada model atau teori sebelumnya, yaitu perceived behavioral control (TPB/ DTPB, C-TAM-TPB), facilitating conditions (MPCU) dan compatibility (IDT) (Venkatesh, 2003: 453).

Kondisi pendukung dalam penggunaan komputer tersebut dapat mempengaruhi pemanfaatan sistem informasi. Sedangkan Oswari Teddy, dkk (2008: 3) menjelaskan empat kondisi pendukung, yaitu: (1) ketersediaan sumber daya, (2) pengetahuan yang memadai untuk menggunakan teknologi, (3) kesesuaian dengan sistem lain yang telah digunakan, dan (4) ketersediaan orang atau sekelompok orang yang bisa membantu pada saat menghadapi kesulitan penggunaan sistem.

Variabel prediktor terakhir adalah self-efficacy. Efikasi diri (self-efficacy) didefinisikan oleh Bandura dalam Hwang dan Yi (2002: 1077) sebagai people's judgments of their capabilities to perform certain activities, yaitu kepercayaan seseorang tentang kapabilitas/ kemampuannya untuk melakukan aktivitas tertentu. Senada dengan definisi di atas, Hwang dan Yi (2002: 1077) mendefinisikan CSE (computer self-efficacy) sebagai perception of one's capability to use a computer. Dalam konteks penelitian ini, self-efficacy diartikan sebagai persepsi mengenai kemampuan diri seseorang untuk menggunakan teknologi internet.

Compeau dan Higgins sebagaimana dikemukakan oleh Wijaya dan Mikhriani (2008: 162) menjelaskan bahwa terdapat 3 (tiga) dimensi self-efficacy, yaitu (1) magnitude, (2) strength dan (3) generalibility. Pertama, dimensi magnitude (besaran) mengacu pada tingkat kapabilitas yang diharapkan dalam penggunaan internet. Individu yang memiliki magnitude self-efficacy yang tinggi diharapkan mampu menyelesaikan tugas-tugas komputasi yang lebih kompleks dibandingkan dengan individu yang memiliki level 
magnitude self-efficacy yang rendah karena kurangnya dukungan maupun bantuan. Kedua, dimensi strength (kekuatan) mengacu pada level keyakinan tentang judgment atau kepercayaan individu untuk mampu menyelesaikan tugas-tugas komputasinya dengan baik. Ketiga, dimensi generalibility mengacu pada tingkat judgment user yang terbatas pada suatu aktivitas domain komputasi tertentu. Individu dengan generalisasibilitas yang tinggi diharapkan mampu dengan baik menggunakan paket software yang berbeda-beda pada sistem komputer yang berbeda pula, sedangkan individu dengan generalisasibilitas yang rendah akan mempersepsikan dirinya sendiri hanya terbatas menggunakan paket software dan sistem komputer tertentu saja.

Kerangka berpikir performance expectancy (ekspektasi kinerja) dalam penelitian ini yang diprediksi berpengaruh terhadap intensi pemanfaatan teknologi internet pada kaum perempuan adalah kemanfaatan dari penggunaan teknologi internet dapat meningkatkan kinerja orang yang menggunakannya. Karenanya, ekspektasi kinerja teknologi internet mempengaruhi intensi dalam menggunakan atau tidak menggunakan teknologi internet tersebut.

Logika berpikir yang melandasi pengujian effort expectancy (ekspektasi usaha) adalah suatu teknologi yang sering digunakan menunjukkan bahwa teknologi tersebut lebih dikenal, mudah dioperasikan dan lebih mudah digunakan. Sedangkan kerangka berpikir social influence (pengaruh sosial) dalam penelitian ini adalah persepsi seseorang bahwa pihak lain percaya bahwa sebaiknya menggunakan teknologi internet merupakan faktor penentu secara langsung terhadap intensi memanfaatkan dan menggunakan teknologi internet.

Logika berpikir yang melandasi pengujian lokus facilitating conditions (kondisi pendukung) adalah sarana dan prasarana organisasi dan teknik sangat berperan dalam penggunaan suatu teknologi tertentu. Kondisi pendukung dalam penggunaan internet tersebut dapat mempengaruhi pemanfaatan teknologi internet. 
Sedangkan variabel terakhir adalah self-efficacy (efikasi diri) Pemikiran yang melandasi pengujian area ini adalah bahwa setiap orang yang merasa yakin bahwa dirinya memiliki kemampuan diri dalam menggunakan teknologi internet, maka akan mempengaruhi intensi perilaku dalam memanfaatkan teknologi internet tersebut.

Bertitik tolak dari kerangka pemikiran teoritis di atas, maka model penelitian yang diketengahkan adalah:

Gambar 2. Model Penelitian

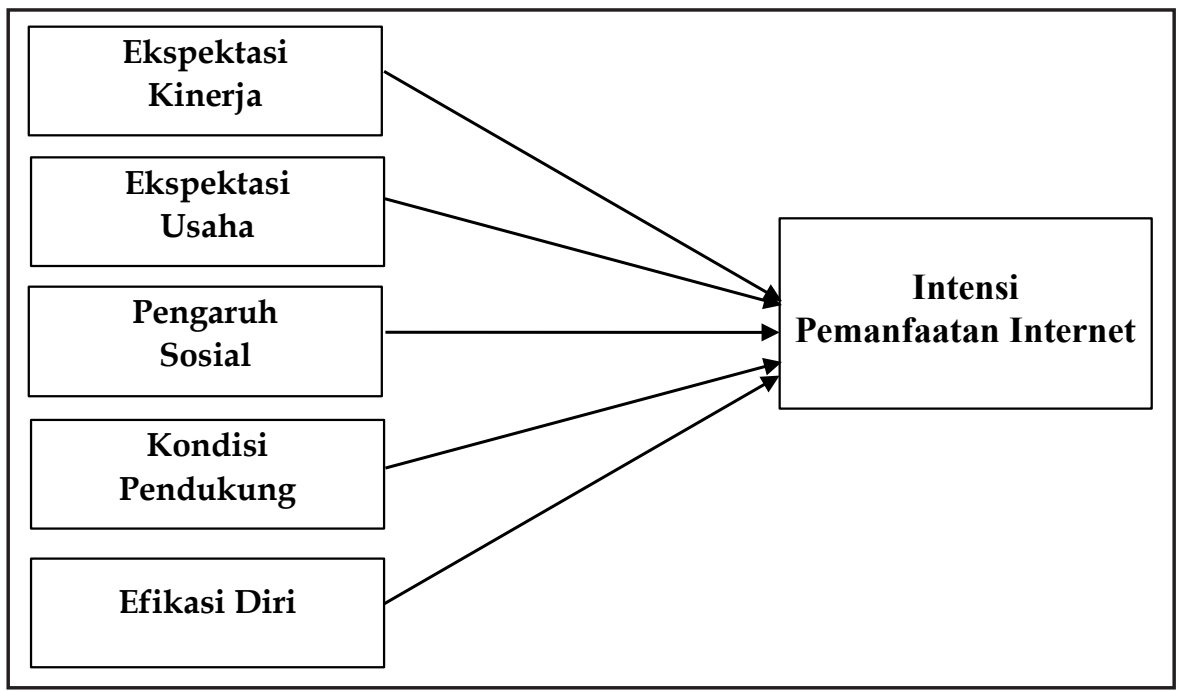

Atas dasar kerangka pemikiran teoritis dan model penelitian tersebut, maka hipotesis yang diuji dalam penelitian ini adalah:

$\mathrm{H}_{1 \text { : }}$ Ekspektasi kinerja berpengaruh secara positif dan signifikan terhadap intensi pemanfaatan internet.

$\mathrm{H}_{2}$ : Ekspektasi usaha berpengaruh secara positif dan signifikan terhadap intensi pemanfaatan internet.

$\mathrm{H}_{3}$ : Pengaruh sosial berpengaruh secara positif dan signifikan terhadap intensi pemanfaatan internet.

$\mathrm{H}_{4}$ : Kondisi pendukung berpengaruh secara positif dan signifikan terhadap intensi pemanfaatan internet.

$\mathrm{H}_{5}$ : Efikasi diri berpengaruh secara positif dan signifikan terhadap 
intensi pemanfaatan internet.

Penelitian ini merupakan jenis penelitian survey, yaitu penelitian yang dilakukan dengan mengambil sampel secara langsung dari populasi, sehingga ditemukan hubungan-hubungan antar variabel (Sugiyono, 2004: 7). Instrumen penelitian menggunakan 6 variabel dari model UTAUT (Unified Theory of Acceptance and Use of Technology), yaitu ekspektasi kinerja, ekspektasi usaha, pengaruh sosial, kondisi pendukung, efikasi diri dan intensi pemanfaatan internet. Sementara itu, kisi-kisi instrumen penelitian sebagai berikut:

Tabel 1. Kisi-Kisi Instrumen Penelitian

\begin{tabular}{|c|l|c|l|}
\hline No & \multicolumn{1}{|c|}{ Variabel } & Item & \multicolumn{1}{c|}{ Reference } \\
\hline 1 & Ekspektasi Kinerja & 4 & Venkatesh, dkk (2003) \\
\hline 2 & Ekspektasi Usaha & 4 & Venkatesh, dkk (2003) \\
\hline 3 & Pengaruh Sosial & 4 & Venkatesh, dkk (2003) \\
\hline 4 & Kondisi pendukung & 4 & Venkatesh, dkk (2003) \\
\hline 5 & Efikasi Diri & 4 & Hwang and Yi (2002) \\
\hline 6 & Intensi Pemanfaatan Internet & 3 & Reid and Levy (2008) \\
\hline
\end{tabular}

Responden penelitian adalah kaum perempuan, baik yang bekerja atau ibu rumah tangga di Kabupaten Kudus. Penentuan sampel dalam penelitian ini dilakukan dengan menggunakan teknik convenience sampling. Dalam penelitian ini, peneliti mengambil sampel sebanyak 110 responden. Kabupaten Kudus terdiri dari 9 kecamatan, yaitu kecamatan Bae, Mejobo, Undaan, Kaliwungu, Kota, Gebog, Jati, Dawe dan Jekulo. Pengambilan sampel di 9 kecamatan di Kabupaten Kudus agar responden memiliki kesempatan yang sama sebagai responden yang mewakili setiap kecamatan serta dapat mengeliminasi subyektifitas dalam penentuan sampel.

\section{Perilaku Pemanfaatan Internet pada kaum Perempuan}

Sebagian besar responden adalah kaum perempuan yang bertempat tinggal di Kecamatan Kota, Bae dan Gebog. Selanjutnya 
disusul beberapa Kecamatan lain, yaitu Kecamatan Mejobo, Jati, Jekulo, Dawe, Undaan dan Kaliwungu.

Sebagian besar responden tergolong familiar dan sudah terbiasa menggunakan fasilitas teknologi informasi dan komunikasi (TIK), seperti komputer, laptop dan internet, bahkan semua responden sudah menggunakan handphone. Jumlah responden yang memiliki komputer pribadi adalah sebanyak 20 orang $(18 \%)$, namun yang memiliki laptop relatif lebih banyak yaitu 42 orang $(38 \%)$, dan yang terbiasa menggunakan internet dan memiliki email adalah sebanyak 46 orang $(42 \%)$ dan 42 orang (38\%). Sedangkan jumlah responden yang pernah mengikuti pelatihan komputer adalah sebanyak 62 orang $(56 \%)$, namun yang pernah mengikuti pelatihan internet hanya sebanyak orang $36(32 \%)$.

Sebagian besar responden, mayoritas jenis pekerjaannya adalah akademisi sebanyak 44 orang $(40 \%)$, PNS sebanyak 12 orang $(11 \%)$, praktisi bisnis sebanyak orang $20(18 \%)$ serta buruh dan penjahit sebanyak 10 orang $(10 \%)$ dan 4 orang $(3 \%)$. Sedangkan responden sebagai ibu rumah tangga sebanyak 20 orang $(18 \%)$.

Secara umum, jenis layanan internet yang paling banyak digunakan responden adalah web browsing $(78 \%)$. Setelah itu, layanan email $(71 \%)$, download file $(71 \%)$ dan facebook $(68 \%)$ juga ikut mendominasi layanan internet yang nota bene banyak disukai responden. Sedangkan jenis layanan internet lainnya yang digunakan responden adalah chatting $(47 \%)$, upload file $(44 \%)$, situs pekerjaan $(40 \%)$ dan situs selebritis $(25 \%)$.

Gambaran perilaku pemanfaatan teknologi internet di kalangan kaum perempuan tersebut menunjukkan bahwa internet sudah menjadi kebutuhan bagi sebagian besar responden, meskipun pemanfaatan jenis layanan internetnya masih bervariasi. Variasi keragaman perilaku pemanfaatan internet tersebut berhubungan dengan persepsi dan pemahaman tentang manfaat internet yang mungkin berbeda-beda antar individu. 
Namun demikian, secara umum responden juga memiliki faktor-faktor pendukung dan menghadapi berbagai kendala atau hambatan dalam pemanfaatan teknologi internet. Faktor pendukung utama responden dalam menggunakan teknologi internet, di antaranya adalah kebutuhan informasi terkini, kebutuhan terhadap ilmu pengetahuan, motif penyelesaian tugas dan komunikasi. Selain itu, kebutuhan untuk memeriksa email dan mencari literatur juga merupakan faktor pendukung kaum perempuan dalam menggunakan teknologi internet. Sedangkan faktor penghambat utama responden untuk tidak menggunakan internet karena faktor kesibukan. Hal ini dapat didukung pula oleh jenis pekerjaan responden adalah ibu rumah tangga, praktisi bisnis, buruh, dan penjahit, yang nota bene mereka sangat disibukkan oleh pekerjaan mereka dan tidak memiliki kesempatan waktu luang untuk menggunakan internet. Selain itu, para responden banyak terlibat dalam pekerjaan domestik yang diakibatkan oleh pembagian peran gender yang kurang adil bagi perempuan Selain itu, faktor penghambat yang lain adalah koneksi lambat, gaptek (gagap teknologi) dan kekurangan waktu.

Berkaitan dengan masalah, tujuan, karakter model dan tipologi ukuran variabel yang dimasukkan dalam model penelitian ini, maka untuk menguji pengaruh independent variable terhadap dependent variable digunakan alat uji statistik yaitu regresi linier berganda.

Setelah dilakukan uji asumsi klasik, yaitu uji multikolinieritas, uji autokorelasi, uji heterokedastisitas, uji normalitas dan uji linieritas menunjukkan bahwa seluruh persyaratan tersebut dapat dipenuhi sehingga dapat dilanjutkan untuk dianalisis dengan model regresi linier berganda.

\section{Koefisien Determinasi}

Untuk mengetahui seberapa besar variabel independen menjelaskan variabel dependen dapat ditentukan dengan koefisien determinasi $\left(\mathrm{R}^{2}\right)$. Hasil perhitungan regresi dengan menggunakan SPSS versi 16.0 menunjukkan nilai koeffisien determinasi $\left(\mathrm{R}^{2}\right)$ 
sebesar 0.803 dan nilai Adjusted $\mathrm{R}^{2}$ adalah 0.793 yang artinya bahwa variabel independen (ekspektasi kinerja, ekspektasi usaha, pengaruh sosial, kondisi pendukung dan efikasi diri) mampu menjelaskan variabel dependen yaitu intensi pemanfaatan internet pada kaum perempuan sebesar $79 \%$.

Tabel 2. Model Summary

\begin{tabular}{|l|r|r|r|r|r|}
\hline Model & $\mathrm{R}$ & $\begin{array}{c}\mathrm{R} \\
\text { Square }\end{array}$ & $\begin{array}{c}\text { Adjusted } \\
\text { R Square }\end{array}$ & $\begin{array}{c}\text { Std. Error of } \\
\text { the Estimate }\end{array}$ & $\begin{array}{c}\text { Durbin- } \\
\text { Watson }\end{array}$ \\
\hline 1 & $.896^{\mathrm{a}}$ & .803 & .793 & 1.571 & 1.775 \\
\hline
\end{tabular}

2. Uji Simultan (F Tes)

Hasil perhitungan regresi berganda menunjukkan nilai $\mathrm{F}$ hitung sebesar 84.690 dengan tingkat signifikansi atau $\mathrm{p}$ value sebesar 0.000. Dengan menggunakan alpha 0.005 maka hipotesis alternatif $(\mathrm{H} 1)$ yang menyatakan bahwa terdapat pengaruh secara simultan (ekspektasi kinerja, ekspektasi usaha, pengaruh sosial, kondisi pendukung dan efikasi diri) terhadap variabel dependen yaitu intensi pemanfaatan internet tidak dapat ditolak karena nilai $\mathrm{p}$ value 0.000 berada jauh di bawah alpha 0.05 ( $\mathrm{p}$ value $0.000<$ alpha 0.05). Untuk lebih jelasnya dapat dilihat pada tabel di bawah ini.

Tabel 3. ANOVA

\begin{tabular}{|c|c|c|c|c|c|c|}
\hline \multicolumn{2}{|c|}{ Model } & $\begin{array}{l}\text { Sum of } \\
\text { Squares }\end{array}$ & $\mathrm{df}$ & $\begin{array}{l}\text { Mean } \\
\text { Square }\end{array}$ & $\mathrm{F}$ & Sig. \\
\hline \multirow[t]{3}{*}{1} & Regression & 1044.614 & 5 & 208.923 & 84.690 & $.000^{\mathrm{a}}$ \\
\hline & Residual & 256.559 & 104 & 2.467 & & \\
\hline & Total & 1301.173 & 109 & & & \\
\hline
\end{tabular}

Uji Partial (Uji t)

Setelah dilakukan uji simultan, selanjutnya dilakukan uji partial yaitu pengujian pengaruh antara masing-masing variabel independen terhadap variabel dependen. Adapun secara rinci uji partial (uji t) dijelaskan dalam tabel berikut ini. 
Tabel 4. Coefficients

\begin{tabular}{|c|c|c|c|c|c|c|}
\hline \multirow{2}{*}{\multicolumn{2}{|c|}{$\begin{array}{l}\text { Model } \\
\text { B }\end{array}$}} & \multicolumn{2}{|c|}{$\begin{array}{c}\text { Unstandardized } \\
\text { Coefficients }\end{array}$} & \multirow[t]{2}{*}{$\begin{array}{c}\text { Standardized } \\
\text { Coefficients }\end{array}$} & \multirow[t]{2}{*}{$\mathrm{T}$} & \multirow[t]{2}{*}{ Sig. } \\
\hline & & $\begin{array}{l}\text { Std. } \\
\text { Error }\end{array}$ & Beta & & & \\
\hline \multirow[t]{6}{*}{1} & (Constant) & 2.725 & .632 & & 4.313 & .000 \\
\hline & EK & .182 & .071 & .218 & 2.559 & .012 \\
\hline & EU & .251 & .090 & .284 & 2.790 & .006 \\
\hline & PS & .041 & .064 & .043 & .646 & .520 \\
\hline & $\mathrm{KP}$ & .180 & .090 & .195 & 2.009 & .047 \\
\hline & ED & .202 & .064 & .242 & 3.162 & .002 \\
\hline
\end{tabular}

$\mathrm{H}_{1}$. Pengaruh Ekspektasi Kinerja Terhadap Intensi Pemanfaatan Internet

Hasil pengujian empirik yang dibantu dengan regresi linier berganda dengan program SPSS versi 16.0 bahwa ekspektasi kinerja secara signifikan dan positif berpengaruh terhadap intensi pemanfaatan internet pada kaum perempuan. Hal ini ditunjukkan dengan nilai t hitung 2.559 dengan nilai signifikansi atau $p$ value 0.012 di mana dengan menggunakan alpha 0.05 maka nilai $\mathrm{p}$ value 0.012 berada jauh di bawah nilai alpha 0.05 . Sementara hubungan positif yang ditunjukkan dengan nilai beta atau slope positif sebesar 0.182 memberi makna bahwa semakin tinggi ekspektasi kinerja kaum perempuan, maka semakin meningkatkan intensi pemanfaatan internet. Dengan demikian, hipotesis pertama terbukti secara statistik. $\mathrm{H}_{2}$. Pengaruh Ekspektasi Usaha terhadap Intensi Pemanfaatan Internet

Hasil perhitungan regresi linier berganda menunjukkan bukti empirik bahwa ekspektasi usaha berpengaruh terhadap intensi pemanfataan internet yang ditunjukkan dengan nilai $t$ hitung sebesar 2.790 dengan nilai $\mathrm{p}$ value atau signifikansi 0.006 dengan menggunakan tingkat alpha 0.05 maka $p$ value berada jauh di bawah alpha 0.05 . Sedang arah hubungan ditunjukkan dengan 
tanda positif pada beta yang memiliki nilai 0.251 yang berarti bahwa terdapat hubungan positif antara ekspektasi usaha dengan intensi pemanfaatan internet. Dengan demikian, hipotesis kedua terbukti secara statistik.

$\mathrm{H}_{3}$. Pengaruh Social Influence (Pengaruh Sosial) terhadap Intensi

Pemanfaatan Internet

Hasil perhitungan regresi linier berganda menunjukkan bukti empirik bahwa pengaruh sosial tidak mempengaruhi intensi pemanfaatan internet yang ditunjukkan dengan nilai $t$ hitung sebesar 0.646 dengan nilai $\mathrm{p}$ value atau signifikansi 0.520 dengan menggunakan tingkat alpha 0.05 maka $\mathrm{p}$ value berada di atas alpha 0.05 . Dengan demikian, hipotesis ketiga tidak terbukti secara statistik.

$\mathrm{H}_{4}$ Pengaruh Kondisi Pendukung Terhadap Intensi Pemanfaatan Internet

Hasil pengujian empirik dengan regresi linier berganda dengan menggunakan program SPSS versi 16.0 bahwa kondisi pendukung berpengaruh terhadap intensi pemanfaatan internet. Hal ini ditunjukkan dengan nilai t hitung 2.009 dengan nilai signifikansi atau $\mathrm{p}$ value 0.047 di mana dengan menggunakan alpha 0.05 maka nilai $\mathrm{p}$ value 0.000 masih di bawah nilai alpha 0.05 . Sedang arah hubungan ditunjukkan dengan tanda positif pada beta yang memiliki nilai 0.180 yang berarti bahwa terdapat hubungan positif antara kondisi pendukung dengan intensi pemanfaatan internet. Dengan demikian, hipotesis keempat terbukti secara statistik.

$\mathrm{H}_{5}$. Pengaruh Efikasi Diri Terhadap Intensi Pemanfaatan Internet

Hasil pengujian empirik dengan regresi linier berganda dengan menggunakan program SPSS versi 16.0 bahwa efikasi diri berpengaruh terhadap intensi pemanfaatan internet. Hal ini ditunjukkan dengan nilai t hitung 3.162 dengan nilai signifikansi atau $p$ value 0.002 di mana dengan menggunakan alpha 0.05 maka nilai $p$ value 0.000 di bawah nilai alpha 0.05 . Sedang arah hubungan ditunjukkan dengan 
tanda positif pada beta yang memiliki nilai 0.202 yang berarti bahwa terdapat hubungan positif antara efikasi diri dengan intensi pemanfaatan internet. Dengan demikian, hipotesis kelima terbukti secara statistik.

Berdasarkan hasil pengujian hipotesis di atas, dapat disimpulkan bahwa dari 5 (lima) hipotesis yang diajukan dalam penelitian ini, terdapat 4 (empat) hipotesis yang didukung oleh data dan 1 (satu) hipotesis yang tidak didukung oleh data. Adapun hasil lengkap pengujian hipotesis penelitian dapat dilihat dalam tabel sebagai berikut:

Tabel 5. Kesimpulan Hipotesis

\begin{tabular}{|c|c|}
\hline \multicolumn{1}{|c|}{ Hipotesis } & Hasil Uji \\
\hline $\mathrm{H}_{1}: \begin{array}{l}\text { Ekspektasi kinerja berpengaruh secara } \\
\text { positif dan signifikan terhadap intensi }\end{array}$ & $\begin{array}{c}\text { Didukung } \\
\text { oleh data }\end{array}$ \\
$\begin{array}{l}\text { pemanfaatan internet. } \\
\mathrm{H}_{2}: \begin{array}{l}\text { Ekspektasi usaha berpengaruh secara } \\
\text { positif dan signifikan terhadap intensi } \\
\text { pemanfaatan internet. }\end{array}\end{array}$ & $\begin{array}{c}\text { Didukung } \\
\text { oleh data }\end{array}$ \\
$\mathrm{H}_{3}: \begin{array}{l}\text { Pengaruh sosial berpengaruh secara } \\
\text { positif dan signifikan terhadap intensi }\end{array}$ & $\begin{array}{c}\text { Tidak didukung } \\
\text { oleh data }\end{array}$ \\
$\begin{array}{l}\text { pemanfaatan internet. } \\
\mathrm{H}_{4}: \begin{array}{l}\text { Kondisi pendukung berpengaruh secara } \\
\text { positif dan signifikan terhadap intensi }\end{array}\end{array}$ & $\begin{array}{c}\text { Didukung } \\
\text { oleh data }\end{array}$ \\
$\begin{array}{l}\text { pemanfaatan internet. } \\
\mathrm{H}_{5}: \text { Efikasi diri berpengaruh secara positif dan } \\
\text { signifikan terhadap intensi pemanfaatan } \\
\text { internet. }\end{array}$ & $\begin{array}{c}\text { Didukung } \\
\text { oleh data }\end{array}$ \\
\hline
\end{tabular}

\section{Simpulan}

Perilaku pemanfaatan teknologi internet pada kaum perempuan di Kabupaten Kudus menunjukkan bahwa sebagian besar responden tergolong familiar dan sudah terbiasa menggunakan fasilitas teknologi informasi, seperti komputer, laptop dan internet, bahkan semua responden sudah menggunakan handphone. Jenis layanan 
internet yang mendominasi dan nota bene paling banyak digunakan responden secara berturut-turut adalah web browsing, layanan email download file facebook (68\%). chatting upload file situs pekerjaan dan situs selebritis. Hal ini mengindikasikan bahwa teknologi internet sudah menjadi kebutuhan bagi sebagian besar responden, meskipun pemanfaatan jenis layanannya masih bervariasi.

Faktor pendukung utama responden dalam menggunakan teknologi internet, di antaranya adalah kebutuhan informasi terkini, tingkat kebutuhan terhadap ilmu pengetahuan, serta motif penyelesaian tugas dan komunikasi. Sedangkan faktor penghambat utama responden untuk tidak menggunakan internet adalah faktor kesibukan, di mana para responden banyak terlibat dalam pekerjaan domestik yang diakibatkan oleh pembagian peran gender yang kurang adil bagi perempuan.

Sedangkan intensi pemanfaatan internet pada kaum perempuan dipengaruhi oleh faktor ekspektasi kinerja, ekspektasi usaha, kondisi pendukung dan efikasi diri. Sedangkan pengaruh sosial tidak berpengaruh secara signifikan terhadap intensi pemanfaatan internet. Temuan penelitian ini menunjukkan pula bahwa efikasi diri merupakan variabel penting yang mempengaruhi intensi perilaku pemanfaatan internet pada kaum perempuan. 


\section{DAFTAR PUSTAKA}

Farida, Ratih, Sri Wulan Windu dan Yudha, Betty. (2010)."Behaviors Model of Internet Use on Women Teachers by Using Unified Theory of Acceptance and Use of Technology" Seminar dan Call for Paper Munas Aptikom Politeknik Telkom, Bandung, 9 Oktober

Halim, Abdul. (2004). Auditing dan Sistem Informasi: Isu-isu Dampak Teknologi Informasi, Yogyakarta: UPP AMP YKPN.

Hermana, Budi, Farida dan Adrianti, Riza. (2007). “Model Adopsi Internet pada Kaum Ibu: Pengembangan dan Pengujian Instrumen Penelitian". Proseding Seminar Nasional Teknologi, Yogyakarta, 24 Nopember

Hernandez, Jose Mauro C. dan Mazzon, Jose Afonso. (2007). "Adoption of Internet Banking: Proposition and Implementation of An Integrated Methodology Approach" dalam International Journal of Bank Marketing, Vol. 25, No. 2,.

Husein, M. Fakhri dan Wibowo, Amin. (2002). Sistem Informasi Manajemen, Yogyakarta: UPP AMP YKPN.

Hwang, Yujong dan Yi, Mun Y. (2002). "Predicting The Use of WebBased Information Systems: Intrinsic Motivation and SelfEfficacy" dalam Eighth Americas Conference on Information Systems,

Najoan, Imelda E. (2006). ”Kepuasan Pemakai terhadap Pemanfaatan Teknologi Informasi dalam Kegiatan Operasional di Coco Supermarket Manado", Tesis. Surabaya: Program Pascasarjana Universitas Airlangga,

Nasution, Fahmi Natigor.(2004). "Penggunaan Teknologi Informasi Berdasarkan Aspek Keperilakuan (Behavioral Aspect)". USU Digital Library.Nurastuti, Wiji. (2011). Teknologi Perbanka. Yogyakarta: Graha Ilmu.

Nurhadi, Indra. (2010). "Variabel-Variabel Yang Mempengaruhi 
Actual System Usage (ASU) Pada Pemanfaatan Studentsite" tersedia dalam http://www.gunadarma.ac.id, diakses pada 7 Juni

Oswari Teddy, Suhendra, E. Susy, dan Harmoni, Ati. (2008). "Model Perilaku Penerimaan Teknologi Informasi: Pengaruh Variabel Prediktor, Moderating Effect, Dampak Penggunaan Teknologi Informasi Terhadap Produktivitas dan Kinerja Usaha Kecil” Seminar Ilmiah Nasional Komputasi dan Sistem Intelijen (KOMMIT), Universitas Gunadarma, Depok, 20-21 Agustus.

Prasetyo, Basuki Hari dan Anubhakti, Dian. (2011) "Kajian Penerimaan Sistem E-Learning dengan Menggunakan Pendekatan UTAUT: Studi Kasus Fakultas Teknologi Informasi Universitas Budi Luhur" BIT, Vol. 8, No. 2, September ISSN: 1693-9166.

Rahmawati dan Subekti Djamaluddin. (2008). "Pengaruh Faktor Individu dan Teknologi terhadap Penerimaan Pembelajaran Berdasar Teknologi Web pada Mahasiswa Akuntansi di Universitas Sebelas Maret", Simposium Nasional Sistem Teknologi Informasi, UGM, 27-28 Januari 2008.

Reid, Michael dan Levy, Yair. (2008).“Integrating Trust and Computer Self-Efficacy with TAM: An Empirical Assessment of Customers' Acceptance of Banking Information System (BIS) in Jamaica", Journal of Internet Banking and Commerce, Vol.12, No.3, December Sedana, I Gusti Nyoman dan Wijaya, St. Wisnu. 2010, "UTAUT Model for Understanding Learning Management System" Internetworking Indonesia Journal, Vol. 2, No.2.

Sugiyono. (2004). Metode Penelitian Bisnis, Bandung: Alfabeta, Suyanto, M., (2005). Teknologi Informasi Untuk Bisnis, Yogyakarta: Penerbit Andi,

Venkatesh, V., Morris, M.G., Davis G.B., dan Davis, F.D. (2003). "User Acceptance of Information Technology : Toward a 
Perempuan dan Pemanfaatan Teknologi Internet dengan Pendekatan UTAUT

Unified View”, MIS Quarterly, Vol. 27, No. 3, Wijaya, Toni dan Mikhriani. (2008). "Pengaruh Computer Anxiety terhadap Computer Self-Efficacy Novice Accountant yang Dimoderasi oleh Locus of Control”, OPTIMAL, Vol. 5, No.2, Februari 
Halaman ini bukan sengaja untuk dikosongkan 